\title{
EDITORIAL
}

\section{THE CHANGING FACE OF ARMY PRIMARY CARE}

In recent years professional advances in standards of primary medical care have acted to favour the formation of group practices and the gathering of Army doctors in what might be called - to borrow a phrase from another part of the medical world - centres of excellence. Such centres of general practice excellence, considered together with a resurgence of professional interest and the advent of vocational training, which have stemmed from the civilian lead and the creation of the Royal College of General Practitioners, have done much to foster and advance the standards of Army care for soldiers and dependants alike. No one should belittle the great progress which General Practice has made in the last decade and it is indeed to be hoped that proper recognition will be afforded to a group of medical officers who constitute a specialist stream - in spirit and dedication, if not in the letter of the law - just as any other specialists in the RAMC.

The present situation contrasts markedly with that obtaining up to and shortly after World War II at which juncture it might be said that the Army witnessed the start of the decline and fall of the Regimental Medical Officer. This took place during a time when the cost effective benefits of group practice were being developed in the forcing house of a severe medical manpower shortage which made it vital that every doctor was deployed to his maximum possible professional advantage. An appraisal of these changes in the light of historical perspective is timely, particularly as it may help to shape proposals for the future of Army Primary Care in peace or war.

Sir Neil Cantlie ${ }^{1}$ describes vividly the arrangements prevailing when Sir James McGrigor joined the Army almost 200 years ago as Regimental Surgeon to the Connaught Rangers; "These were the days when the Regimental Surgeon owed loyalty to the Colonel of his Regiment, on the same footing as his brother combatant officers and he wore the regimental uniform. Every Regiment had its own Regimental Hospital of 12 equipped beds, and here the sick lived and died, for in peace-time there were no other military hospitals in existence." Regimental doctors have been a feature of the Army Medical Services ever since, particularly so in war time; the many recorded accounts of valour and the even more numerous and appreciative reports from Commanding Officers of Combatant Units bear witness to this. But today only the Household Cavalry preserves the old custom of regimental commissions for doctors. For the rest the RAMC officer who wears the insignia of the regiment to which he is posted, be it kilt, cap badge or belt, is today a rarity. Although formal establishment tables may continue to provide for a regimental doctor the incumbent of such appointments is more often than not to be found working in the garrison or station group practice.

Is it entirely a good and welcome change that the Regimental Medical Officer has virtually disappeared from the peace-time de facto organization? Undoubted- 
ly, as has been stated at the outset, the cost effectiveness of primary care has been appreciably enhanced but there linger some doubts as to whether or not the pendulum has swung too far away from the doctor dedicated solely to the care of his Regiment and its dependants in favour of the less personal but efficient group practice system. Battalion and Regimental Commanders are convincingly articulate in their defence of the Unit doctor. To a certain extent their case for the defence represents a CO's natural wish for a personalised service, but nevertheless there is merit in the argument that the RMO is a better doctor when he has the the opportunity to study and understand his potential patients (or non-patients if preventive activities are successful) in their working military environment. There is much to be said in favour of the doctor who goes out among the military community, who studies and pre-empts the multiplicity of present day technological health hazards, both physical and psychological. Such a doctor surely does a better job for medicine and for the Army than one who is content to sit comfortably behind his consulting room desk waiting to treat, advise and cure those patients who present? In reality the question is not as simple as posed here; the factors are complex and the best solution is not easy to find. Much the same question is asked in another way in the correspondence columns of this issue ${ }^{2}$ and it is manifest that there are arguments both for and against the future role of the regimental medical officer.

This brief but provocative essay will have been successful if it activates, and serves as a catalyst to stimulate, constructive discussion and controversy about the future of primary care doctoring in the Army.

\section{REFERENCES}

1. Cantlie, Sir Neil. Sir James McGrigor. J R Army Med Corps 1971; 117: 51-58.

2. Finnegan, T P. Whither the RMO? J R Army Med Corps 1981; 127: 104-105. 